\title{
PRODUCTION OF RARE EARTH ELEMENTS FROM MALAYSIAN MONAZITE BY SELECTIVE PRECIPITATION
}

\section{(Penghasilan Unsur Nadir Bumi daripada Mineral Monazit Menggunakan Pemendakan Terpilih)}

\author{
Che Nor Aniza Che Zainul Bahri*, Wadeeah M. Al- Areqi, Amran Ab. Majid, Mohd Izzat Fahmi Mohd Ruf \\ Nuclear Science Program, School of Applied Physics, \\ Faculty of Science and Technology, \\ Universiti Kebangsaan Malaysia, 43600 UKM Bangi, Selangor, Malaysia \\ *Corresponding author: anizazainul@gmail.com
}

Received: 2 November 2015; Accepted: 31 December 2015

\begin{abstract}
Rare earth elements (REEs) are very valuable and have high demands for advanced technology nowadays. REEs can be classified to light rare earth elements (LREEs) and heavy rare earth elements (HREEs). Malaysian rare earth ore especially monazite, is rich with LREEs compared to HREEs. Therefore a study was carried out to extract the REE from Malaysian monazite. The objectives of this study are to determine the content of REEs in Malaysian monazite leach solution, as well as to produce high grade of REEs. Concentrated sulphuric acid was used in digestion process and the filtrate containing the REEs was determined using Inductively Coupled Plasma- Mass Spectrometry (ICP-MS). Ammonia solution was used for REEs precipitation from monazite leach solution. The result indicated that REEs was successfully separated from monazite leach solution through selective precipitation using ammonia at $\mathrm{pH} 2.34$ and the percentage of REEs that successfully separated was $70.03-81.85 \%$. The percentage of REEs which successfully separated from final solution was $96.05-99.10 \%$. Therefore, to have high purification of individual REEs, solvent extraction process should be carried out.
\end{abstract}

Keywords: monazite, rare earth elements (REEs), separation, selective precipitation

\begin{abstract}
Abstrak
Unsur nadir bumi sangat berharga dan mempunyai permintaan yang tinggi dalam teknologi termaju masa kini. Unsur nadir bumi dapat dikelaskan kepada unsur nadir bumi ringan (LREEs) dan unsur nadir bumi berat (HREEs). Bijih nadir bumi Malaysia terutamanya monazit kaya dengan unsur nadir bumi ringan berbanding unsur nadir bumi berat. Dengan itu, satu kajian telah dilakukan untuk mengekstrak unsur nadir bumi dari monazit Malaysia. Objektif kajian ini adalah untuk menentukan kandungan unsur nadir bumi dalam larutan larut lesap monazit Malaysia serta menghasilkan unsur nadir bumi bergred tinggi. Asid sulfurik pekat telah digunakan untuk menghadamkan monazit dan hasil turasan yang mengandungi unsur nadir bumi ditentukan menggunakan ICP-MS. Larutan ammonia telah digunakan untuk memendakan torium daripada unsur nadir bumi dari larutan larut lesap monazit. Keputusan kajian mendapati unsur nadir bumi berjaya diasingkan dari larutan larut lesap monazit melalui mendakan terpilih menggunakan ammonia pada $\mathrm{pH} 2.34$ dan peratus unsur nadir bumi yang berjaya diasingkan adalah antara $70.03-81.85 \%$. Peratus unsur nadir bumi yang berjaya diasingkan daripada larutan akhir pula adalah 96.05 - 99.10\%. Oleh itu, bagi menghasilkan unsur nadir bumi yang berketulenan tinggi maka proses pengekstrakan pelarut perlu dilakukan.
\end{abstract}

Kata kunci: monazit, unsur nadir bumi, pengasingan, pemendakan terpilih 


\section{Che Nor Aniza et al: PRODUCTION OF RARE EARTH ELEMENTS FROM MALAYSIAN MONAZITE BY SELECTIVE PRECIPITATION}

\section{Introduction}

Rare earths elements (REEs) are series of chemical elements found in the rare earth's crust that are vital to many modern technologies including consumer electronics, computers and networks, clean energy, communication, advanced transportation, health care and many others. There are 17 elements that are considered to be rare earth elements which are 15 elements in the lanthanide series and 2 additional elements that share similar chemical properties. 15 elements in lanthanide series are Lanthanum (La), Cerium (Ce), Praseodymium (Pd), Neodymium (Nd) and Samarium (Sm) that are classified as light rare earth elements (LREEs) meanwhile Europium (Eu), Gadolinium (Gd), Terbium (Tb), Dysprosium (Dy), Holmium (Ho), Erbiumthulium (Er) and Ytterbium (Yb) are classified as heavy rare earth elements (HREEs). Another two additional elements are Scandium (Sc) and Yttrium (Y) [1].

REEs are often found together in nature at low concentrations in various minerals. About $95 \%$ of the rare earths occur in only three minerals: bastnasite, monazite, and xenotime [2]. In Malaysian, monazite and xenotime are minerals phosphates that are present as by-product of tin mining processing. Many reports cite that Malaysia has reasonably substantial amounts of REEs. In facts, Malaysia has about 30,000 tonnes of rare earths based on the finding in the residual tin deposits [3]. Monazite contains more LREEs compared to HREEs that are associated together with NORM (Thorium and Uranium) in significant concentration. Monazite concentrate commonly contains $24.0-29.0 \%$ of phosphate $\left(\mathrm{P}_{2} \mathrm{O}_{5}\right), 55.0$ - 60.0\% rare earth metal oxides, $5.0-10.0 \%$ thorium oxide $\left(\mathrm{ThO}_{2}\right)$ and $0.2-0.4 \%$ uranium oxide $\left(\mathrm{U}_{3} \mathrm{O}_{8}\right)$ [4].

Various processing routes have been developed to recover rare earths elements from minerals. After mining, ore is beneficiated by flotation, magnetic or gravity methods to produce rare earth concentrates, which then undergo hydrometallurgical processing to recover rare earth metals or compounds [5]. The chemical treatment of monazite can be carried out via the alkaline through sodium hydroxide or via the acid by means of sulphuric acid digestion. Sulphuric acid digestion is the classical method which has been used for many years by the processing industry. The monazite leach solution produced through digestion with sulphuric acid contains REEs and others elements such as $\mathrm{Th}, \mathrm{U}$ as well as phosphoric acid and excess sulphuric acid. The reaction of monazite and concentrated sulphuric acid is shown by equation $1-3$ below [4]:

$$
\begin{array}{ll}
2 \mathrm{RE}\left(\mathrm{PO}_{4}\right)+3 \mathrm{H}_{2} \mathrm{SO}_{4} \longrightarrow & \mathrm{RE}_{2}\left(\mathrm{SO}_{4}\right)_{3}+2 \mathrm{H}_{2} \mathrm{PO}_{4} \\
\mathrm{ThSiO}_{4}+2 \mathrm{H}_{2} \mathrm{SO}_{4} \longrightarrow & \begin{array}{l}
\mathrm{Th}\left(\mathrm{SO}_{4}\right)_{2}+\mathrm{SiO}_{2}+2 \mathrm{H}_{2} \mathrm{O} \\
\mathrm{Th}_{3}\left(\mathrm{PO}_{4}\right)_{4}+6 \mathrm{H}_{2} \mathrm{SO}_{4} \longrightarrow
\end{array} \\
3 \mathrm{Th}\left(\mathrm{SO}_{4}\right)_{2}+4 \mathrm{H}_{2} \mathrm{PO}_{4}
\end{array}
$$

The high commercial value of the REEs depends on their purity and the quality of the compounds. In order to separate REEs from monazite leach solution, first selective precipitate was used to remove the thorium. The most common and promising precipitation methods are acidity control using precipitating agent. Selection of precipitating agent will depend on the specific composition of monazite leach solution. Traditionally, precipitation has been viewed from a chemical equilibrium and an inorganic cation or anion removal perspective [2]. Reducing the acidity of monazite leach solution at a $\mathrm{pH}$ of 1,3, and 6 can precipitate Th, REEs and U respectively [6 7]. Meanwhile study by Gupta \& Krisnamurty (2005) was showed the monazite leach solution is subsequently diluted with precipitating agent for neutralization to yield precipitates containing mainly thorium at $\mathrm{pH} 1.05$, rare-earth at pH 2.3 and uranium at $\mathrm{pH} 6$ [5]. Davis used sodium carbonate or sodium hydroxide to partially neutralize the monazite leach solution [8]. Meanwhile ammonia hydroxide [9] or magnesia [10] could be used to partially neutralize the monazite leach solution.

Monazite concentrate can contain up to $70 \%$ of REEs [11]. An ability to separate the REEs more than $70 \%$ can produce high grade REEs. Therefore, the objectives of this study are to determine the content of REEs in monazite leach solution as well as to produce high grade of REEs.

\section{Preparation of monazite leach solution}

\section{Materials and Methods}

Monazite sample used in this study were originally from 'amang' factory in Perak. The monazite leach solution were prepared by digesting approximately $25 \mathrm{~g}$ of monazite in $50 \mathrm{ml}$ of $98 \%$ sulphuric acid for 3- 4 hours at $200-$ 
$230^{\circ} \mathrm{C}$ on the stirring hot plate, the mixture then was cooled to room temperature. Distilled water was added to dissolve the metal sulphates, and filtered to produce a clear solution. This clear solution was called as monazite leach solution. The monazite leach solution was diluted with distilled water to $250 \mathrm{~mL}$. The content of REEs in monazite leach solution was determined using ICP-MS. The ICP-MS instrument used was an ELAN 9000 (PerkinElmer SCIEX). Prior to ICP-MS analyses, standard solution was prepared using PerkinElmer Pure Plus (multi-element calibration standard 2). It is noted that $100 \mathrm{~mL}$ of the $250 \mathrm{~mL}$ monazite leach solution was taken for the REEs and thorium analysis.

\section{Selective precipitation of REE with ammonia solution}

The acidity of monazite leach solution which contains REEs, thorium and uranium was reduced at differences $\mathrm{pH}$ by using ammonia solution. The measurements of $\mathrm{pH}$ were done using EUTECH instruments $\mathrm{pH} 700.100 \mathrm{~mL}$ of monazite leach solution was adjusted $\mathrm{pH}$ around $1.08-1.84$ with ammonia $(13.4 \mathrm{M})$ and was filtered to separate thorium. The content of REEs in filtrate solution was determined via ICP-MS. The filtrate solution again was adjusted the $\mathrm{pH} 2.34-3.43$ with ammonia $(13.4 \mathrm{M})$ to precipitate the REEs. After filtration, total REEs concentrations in the REEs precipitate was determined by dissolving it in hydrochloric acid and analysed via ICPMS and final solution was also determined for total content of elements. Separation percentage of REEs from monazite leach solution was calculated. The flowchart REEs separation from monazite was summarized as shown in Figure 1.

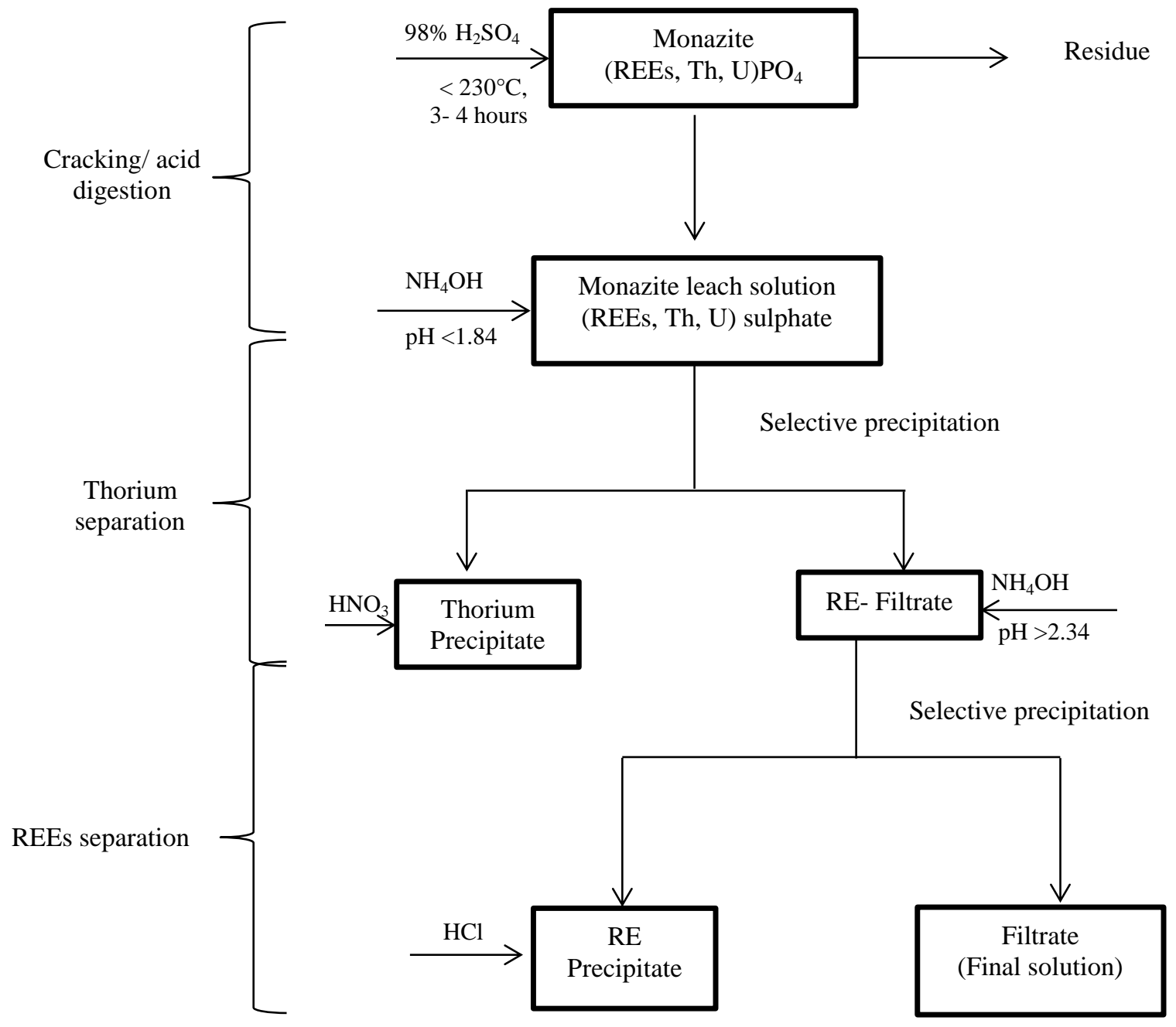

Figure 1. Simplified flowchart of REEs separation from monazite leach solution 
The content of REEs in monazite leach solution

\section{Results and Discussion}

The result of REEs contained in $100 \mathrm{~mL}$ monazite leach solution was presented in Table 1. There are six LREEs and seven HREEs were determined by ICP-MS. The total concentration LREEs in $100 \mathrm{~mL}$ of monazite leach solution were $\mathrm{Ce}, \mathrm{La}, \mathrm{Nd}, \mathrm{Pr}, \mathrm{Gd}$ and $\mathrm{Sm}$ which contain 131.25, 75.87, 53.33, 14.77, 12.29 and $11.11 \mathrm{mg}$ respectively. Meanwhile the HREEs determined were in range of 1.93-15.41 mg. The total content of LREEs were $298.62 \mathrm{mg}$ and their amounts represent $69.17 \%$ of the total element in monazite leach solution. Monazite contains up to $70 \%$ REEs, primarily Ce and La as well as significant amount of Nd, Pr and Sm, from LREEs group [11]. The result shown clearly the content of LREEs was more abundant compared to HREEs in Malaysian monazite. Meanwhile, the monazite leach solution was prepared also contains significant amount of thorium. The presence of thorium in monazite leach solution was quite high, which is a concern in REEs separation processing. This study shown the percentage of thorium was contained in monazite leach solution more than HREEs. The percentage of thorium in $100 \mathrm{~mL}$ monazite leach solution determined was $19.40 \%$ compared to HREEs was $11.43 \%$. This way was normal because the monazite mineral was considered as a source of world supply for both LREEs and thorium [12], whereas the higher content of HREEs could be found in xenotime and bastenite.

Table 1. The mean content of light rare earth elements, heavy rare earth elements and Thorium in $100 \mathrm{~mL}$ monazite leach solution

\begin{tabular}{|c|c|c|c|c|c|}
\hline LREES & $\begin{array}{l}\text { Total content of } \\
\text { elements in } 100 \mathrm{ml} \text { of } \\
\text { leach solution }(\mathrm{mg})\end{array}$ & HREES & $\begin{array}{l}\text { Total content of } \\
\text { elements in } 100 \mathrm{ml} \text { of } \\
\text { leach solution }(\mathrm{mg})\end{array}$ & NORM & $\begin{array}{l}\text { Total content of } \\
\text { elements in } 100 \mathrm{ml} \text { of } \\
\text { leach solution }(\mathrm{mg})\end{array}$ \\
\hline $\mathrm{La}$ & $75.87 \pm 1.19$ & $\mathrm{~Tb}$ & $1.93 \pm 0.02$ & $\mathrm{Th}$ & $83.76 \pm 1.17$ \\
\hline $\mathrm{Ce}$ & $131.25 \pm 0.91$ & Dy & $13.31 \pm 0.10$ & & \\
\hline $\operatorname{Pr}$ & $14.77 \pm 0.26$ & Ho & $3.07 \pm 0.41$ & & \\
\hline $\mathrm{Nd}$ & $53.33 \pm 0.24$ & $\mathrm{Er}$ & $11.14 \pm 0.14$ & & \\
\hline $\mathrm{Sm}$ & $11.11 \pm 0.08$ & $\mathrm{Tm}$ & $2.01 \pm 0.36$ & & \\
\hline \multirow{2}{*}{ Gd } & \multirow{2}{*}{$12.29 \pm 0.21$} & $\mathrm{Yb}$ & $15.41 \pm 0.55$ & & \\
\hline & & $\mathrm{Lu}$ & $2.49 \pm 0.09$ & & \\
\hline$\Sigma$ LREES & 298.62 & ¿HREES & 49.36 & इNORM & 83.76 \\
\hline$\%$ & 69.17 & & 11.43 & & 19.40 \\
\hline
\end{tabular}

Separation of REEs from monazite leaches solution

As mentioned above, monazite leach solution contains high concentration of thorium that should be removed first. Thorium is a radioactive element but it is valuable to use in nuclear reactor as nuclear fuel. Therefore, thorium was removed from monazite leach solution by gradually reducing the acidity until the insoluble thorium phosphate precipitated. The REEs phosphates were more soluble and remained in solution. Precipitation of thorium by ammonia solution at $\mathrm{pH}<1.84$ was done and the result was indicated in Table 2.

The result shown that an only small amount of REEs was precipitated and more than $96 \%$ of REEs left in the filtration. Kernal (1953) reported that at $\mathrm{pH} 1.6,99 \%$ of thorium had precipitated together with only a few percent of REEs [13]. However, this study showed at $\mathrm{pH} 1.08-1.84$ about $97.68 \%$ of thorium was precipitated with presence only 1.61-3.08\% of REEs. The total percentages of LREEs and HREEs in the filtrates are 97.33 and 97.93\% respectively. It clearly showed that total percentage in rare earth filtrate for both LREEs and HREEs have no significant difference. The content of REEs in rare earth filtrate was in range $1.89 \pm 0.06-127.58 \pm 3.77 \mathrm{mg}$. 
The higher content of REEs in rare earth filtrate was continued with second precipitation using ammonia solution at $\mathrm{pH}$ more than 2.34 and the result was shown in Table 3. The total content of LREEs and HREEs in rare earth precipitated were 230.95 and $36.21 \mathrm{mg}$ respectively. From the result, the content of REEs determined in final solution very low was in range $0.04-2.59 \mathrm{mg}$. In comparison the total percentage of separation for LREEs and HREEs, the LREEs has shown the high total percentage separation was $98.18 \%$ whereas HREEs was $95.36 \%$. The highest percentage separation was $99.10 \%$ of Sm while the separation of Ce which represents the major constituent of the LREEs was about $98.61 \%$. On the other hand, for HREEs the Tb has shown high percentage of separation about $97.93 \%$. Meanwhile, the content of thorium in final solution was $0.01 \pm 0.00 \mathrm{mg}$ and in percent of separation was $99.99 \%$. Based on this result, it means almost all the thorium was successfully separated from the REEs.

Table 2. The mean content of REEs and Thorium in rich rare earth filtrate

\begin{tabular}{|c|c|c|c|c|}
\hline $\begin{array}{l}\text { Atomic } \\
\text { number }\end{array}$ & Elements & $\begin{array}{r}\text { Total content of elements } \\
\text { in } 100 \mathrm{ml} \text { of leach solution } \\
(\mathrm{mg})\end{array}$ & $\begin{array}{l}\text { Total content of REEs } \\
\text { in RE- filtrate (mg) }\end{array}$ & $\begin{array}{r}\text { Percentage of } \\
\text { separation }(\%)\end{array}$ \\
\hline \multicolumn{5}{|l|}{ LREEs } \\
\hline 57 & $\mathrm{La}$ & $75.87 \pm 1.19$ & $74.28 \pm 1.80$ & 97.90 \\
\hline 58 & $\mathrm{Ce}$ & $131.25 \pm 0.91$ & $127.58 \pm 3.77$ & 97.20 \\
\hline 59 & $\operatorname{Pr}$ & $14.77 \pm 0.26$ & $14.32 \pm 0.56$ & 96.95 \\
\hline 60 & $\mathrm{Nd}$ & $53.33 \pm 0.24$ & $51.69 \pm 1.41$ & 96.92 \\
\hline 62 & $\mathrm{Sm}$ & $11.11 \pm 0.08$ & $10.78 \pm 0.37$ & 97.03 \\
\hline \multirow[t]{2}{*}{64} & $\mathrm{Gd}$ & $12.29 \pm 0.21$ & $11.99 \pm 0.43$ & 97.56 \\
\hline & ¿LREEs & 298.62 & 290.64 & 97.33 \\
\hline \multicolumn{5}{|l|}{ HREES } \\
\hline 65 & $\mathrm{~Tb}$ & $1.93 \pm 0.02$ & $1.89 \pm 0.06$ & 97.93 \\
\hline 66 & Dy & $13.31 \pm 0.10$ & $13.02 \pm 0.44$ & 97.82 \\
\hline 67 & Ho & $3.07 \pm 0.41$ & $3.01 \pm 0.08$ & 98.05 \\
\hline 68 & Er & $11.14 \pm 0.14$ & $10.91 \pm 0.28$ & 97.94 \\
\hline 69 & $\mathrm{Tm}$ & $2.01 \pm 0.36$ & $1.97 \pm 0.04$ & 98.01 \\
\hline 70 & $\mathrm{Yb}$ & $15.41 \pm 0.55$ & $15.09 \pm 0.28$ & 97.92 \\
\hline \multirow[t]{2}{*}{71} & $\mathrm{Lu}$ & $2.49 \pm 0.09$ & $2.45 \pm 0.06$ & 98.39 \\
\hline & इHREEs & 49.36 & 48.34 & 97.93 \\
\hline \multicolumn{5}{|l|}{ NORM } \\
\hline 90 & Th & $83.76 \pm 1.17$ & $1.94 \pm 1.17$ & 2.32 \\
\hline
\end{tabular}

The percentage of individual precipitate at $\mathrm{pH}<1.84$ and $\mathrm{pH}>2.34$ was illustrated in Figure 2. It is clear that recovery of REEs at $\mathrm{pH}>2.34$ was above $70 \%$. Meanwhile, less than $5 \%$ of REEs was precipitated at $\mathrm{pH}<1.84$. It can figure out that most of REEs was separated during ammonia precipitation and the optimum $\mathrm{pH}$ for REEs removal was in $\mathrm{pH}>2.34$. In addition to the effect of different $\mathrm{pH}$, concentration of ammonia as a precipitant affect was affected of the separation percentage results. This study shown the percentage of REEs was successfully separated was in range $96.05-99.10 \%$. Monazite can contain up to $70 \%$ REEs [11] and in this experiment was shown more than $70 \%$ of REEs was separated. It implies the high grade REEs was successfully produced via selective precipitation at selected $\mathrm{pH}$ value. 
Che Nor Aniza et al: PRODUCTION OF RARE EARTH ELEMENTS FROM MALAYSIAN MONAZITE BY SELECTIVE PRECIPITATION

Table 3. The separation percentage of REEs and Thorium from monazite leach solution

\begin{tabular}{|c|c|c|c|c|c|}
\hline $\begin{array}{l}\text { Atomic } \\
\text { number } \\
(\mathrm{Z})\end{array}$ & Elements & $\begin{array}{r}\text { Total content of } \\
\text { elements in } 100 \mathrm{ml} \text { of } \\
\text { leach solution } \\
(\mathrm{mg})\end{array}$ & $\begin{array}{r}\text { Total content of } \\
\text { Elements in RE } \\
\text { precipitate } \\
(\mathbf{m g})\end{array}$ & $\begin{array}{r}\text { Total content } \\
\text { of REEs in } \\
\text { final solution } \\
(\mathrm{mg})\end{array}$ & $\begin{array}{r}\text { Percentage of } \\
\text { Separation } \\
(\%)\end{array}$ \\
\hline \multicolumn{6}{|l|}{ LREES } \\
\hline 57 & $\mathrm{La}$ & $75.87 \pm 1.19$ & $62.10 \pm 16.62$ & $2.59 \pm 0.92$ & 96.59 \\
\hline 58 & $\mathrm{Ce}$ & $131.25 \pm 0.91$ & $101.71 \pm 18.86$ & $1.82 \pm 0.75$ & 98.61 \\
\hline 59 & $\operatorname{Pr}$ & $14.77 \pm 0.26$ & $10.94 \pm 1.75$ & $0.16 \pm 0.06$ & 98.92 \\
\hline 60 & $\mathrm{Nd}$ & $53.33 \pm 0.24$ & $39.19 \pm 6.50$ & $0.54 \pm 0.25$ & 98.99 \\
\hline 62 & $\mathrm{Sm}$ & $11.11 \pm 0.08$ & $7.78 \pm 1.18$ & $0.10 \pm 0.05$ & 99.10 \\
\hline \multirow[t]{2}{*}{64} & $\mathrm{Gd}$ & $12.29 \pm 0.21$ & $9.23 \pm 2.33$ & $0.22 \pm 0.09$ & 98.21 \\
\hline & & 298.62 & 230.95 & 5.43 & 98.18 \\
\hline \multicolumn{6}{|l|}{ HREES } \\
\hline 65 & $\mathrm{~Tb}$ & $1.93 \pm 0.02$ & $1.44 \pm 0.37$ & $0.04 \pm 0.01$ & 97.93 \\
\hline 66 & Dy & $13.31 \pm 0.10$ & $9.68 \pm 2.18$ & $0.31 \pm 0.11$ & 97.67 \\
\hline 67 & Но & $3.07 \pm 0.41$ & $2.26 \pm 0.55$ & $0.09 \pm 0.03$ & 97.07 \\
\hline 68 & $\mathrm{Er}$ & $11.14 \pm 0.14$ & $8.24 \pm 2.05$ & $0.44 \pm 0.01$ & 96.05 \\
\hline 69 & $\mathrm{Tm}$ & $2.01 \pm 0.36$ & $1.50 \pm 0.42$ & $0.07 \pm 0.02$ & 96.52 \\
\hline 70 & $\mathrm{Yb}$ & $15.41 \pm 0.55$ & $11.26 \pm 2.68$ & $0.44 \pm 0.11$ & 97.14 \\
\hline \multirow[t]{2}{*}{71} & $\mathrm{Lu}$ & $2.49 \pm 0.09$ & $1.83 \pm 0.45$ & $0.09 \pm 0.02$ & 96.39 \\
\hline & & 49.36 & 36.21 & 2.29 & 95.36 \\
\hline NORM & & & & & \\
\hline & Th & $83.76 \pm 1.17$ & $2.49 \pm 2.31$ & $0.01 \pm 0.00$ & 99.99 \\
\hline
\end{tabular}

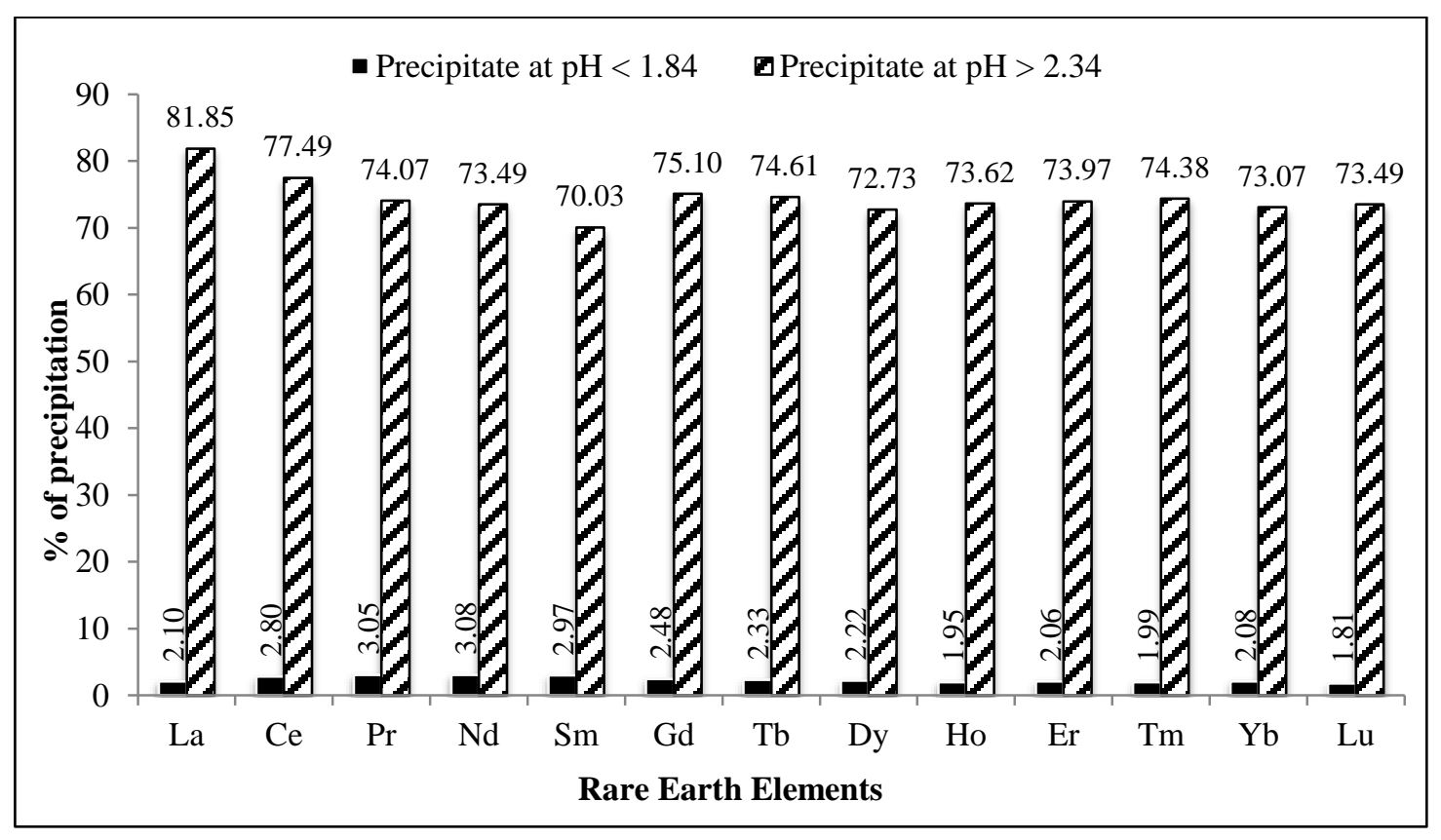

Figure 2. Percentage of individual REEs precipitated with ammonia solution at $\mathrm{pH}<1.84$ and $\mathrm{pH}>2.34$ 
This experiment will be continued by purification process to produce high-purity REEs. The resulting solution then will undergo further purification by solvent extraction with organic extractants in kerosene. Commercially, there are three organic extractant are chosen i.e di(2ethylhexyl)phosphoric acid $\left(\mathrm{D}_{2} \mathrm{EHPA}\right)$, Tributylphosphate (TBP) and aliquat-336. The solvent extraction is usually used to separate individual REEs or produce mixed rare earth compounds.

\section{Conclusion}

Monazite leach solution was prepared by digesting the monazite with concentrated sulphuric acid. The content of REEs in the monazite leach solution is rich with LREEs with percentage $69.17 \%$ compared to HREEs only $11.43 \%$. The presence of thorium in monazite leach solution was quit high. The REEs was separated from monazite leach solution through selective precipitation using ammonia at $\mathrm{pH}>2.34$ and the recovery percentage of REEs was $70.03-81.85 \%$. The percentage of REEs was successfully separated from final solution was $96.05-99.10 \%$. Therefore, high grade REEs can be obtained by selective precipitation from monazite leach solution. In order to have high purification of individual REEs, multistage solvent extraction should be carried out.

\section{Acknowledgement}

The authors would like to acknowledge the Ministry of High Education and Ministry of Science Technology and Innovation for the funding this work through FRGS/ 1/ 2013/ ST01/UKM/01/2 and FP0214D052-01-2.4 DSTIN respectively. Many thanks to Universiti Kebangsaan Malaysia for the support and encouragement.

\section{References}

1. Environment Protection Agency. (2012). Rare Earth Elements: A Review of production, processing, recycling and associated environmental issues.

2. Gupta C. K. and N. Krishnamurthy. (1992). Extractive metallurgy of rare earths. International Materials Reviews 1992, 37 (5): 197

3. Academy of Science Malaysia \& The National Professors' Council. (2011). Rare Earth Industries: Moving Malaysia's Green Economy Forward. Perpustakaan Negara Malaysia. ISBN 978-983-9445-69-5.

4. Gupta C. K, and Mukherjee T. K. (1990). Hydrometallurgy in extraction process. Library of Congress, 1: 901561, ISBN 0-8493-6804. Printed by United States.

5. Gupta, C.K, and N. Krishnamurthy. (2005). Extraction Metallurgy of Rare Earths. Taylor \& Francis e-Library, Boca Raton, New York, Washington, DC. ISBN 0-20367180-5.

6. Hughes, K. C. and Singh, R. (1980). The isolation of thorium from monazite by solvent extraction. Hydrometallurgy, 6 (1-2): 25 - 33.

7. Wickleder, M. S., Fourest, B. and Dorhout,P. K. (2010). Thorium. The Chemistry of the Actinide and Transactinide Elements, 1- 6 (4): $52-160$.

8. Davis, C. W. (1921). Thorium compounds from monazite sands. U. S. Patent 1,368,243.

9. Rollefson, A. K. and Hogeman, P. (1947). Chemistry of thorium. Preliminary Draft PPR. Vol. 17A. Ch. VII. U. S. Atomic Energy Commission, CB-3717. April 17, 1947.

10. Spencer, J. P. (1919). The metals of the rare earths. London; Longmans, Green, and Co.

11. Peelman, S. Sun, Z. H. I., Sietsma, J. and Yang, Y. (2014). Leaching of rare earth elements: past and present. 1st European Rare Earth Resources Conference Milos|04-07/09/2014

12. Ahmed, S.H., Helaly, O. S., Abd El-Ghany, M. S. (2015). Evaluation of Rare Earth Double Sulphate Precipitation from Monazite Leach Solutions. International Journal of Inorganic and Bioinorganic Chemistry, $5(1): 1-8$.

13. Kernal Glenn Shaw. (1953). A process for separating thorium compounds from monazite sands. Iowa State University. Retrospective Theses and Dissertation. 